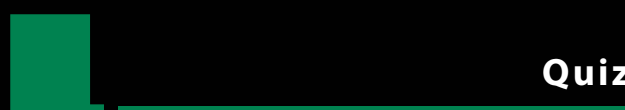

$\square$

\title{
Tumoren - älter als die Menschheit?
}

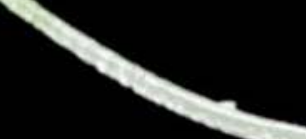

Auf der Suche nach dem Ursprung von Onkogenen fan'den Forscher des Max-Planck-Instituts für Evolutionsbiologie heraus, dass bereits die evolutionär ersten Tierarten viele Gene tragen, die sowohl bei diesen selbst, als auch beim Menschen zu Tumoren führen. Kaum vorstellbar, dass korallenähnliche Polypen an tumorartigen Zellhaufen leiden, die Defekte in der ZelltodMaschinerie aufweisen, ganz so wie mutierte Zellen in humanen Tumoren. Nicht nur Onkogene, sondern auch ihr Einfluss auf die Krebszellen scheinen steinalt zu sein.

Julia Rustemeier

Wie lautet der Name des ältesten bekannten Onkogens?

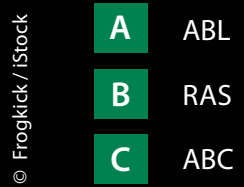

Der Buchstabe der richtigen Antwort ist

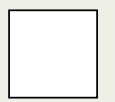

\section{Name}

\section{Straße, Nr.}

\section{PLZ, Ort}

Was ich noch sagen wollte ...

Coupon bitte ausfüllen und abschicken an Springer Medizin Verlag $\mathrm{GmbH}$ Redaktion Im Focus Onkologie - Quiz 11/2015 Aschauer Straße 30, 81549 München

Oder senden Sie uns eine E-Mail an doris.berger@springer.com

Einsendeschluss: 16.12.2015

Und das können

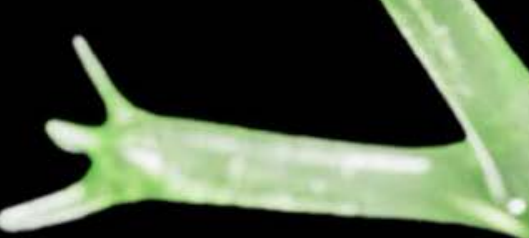

\section{Sie gewinnen ...}

Alles, was Wissen schafft.

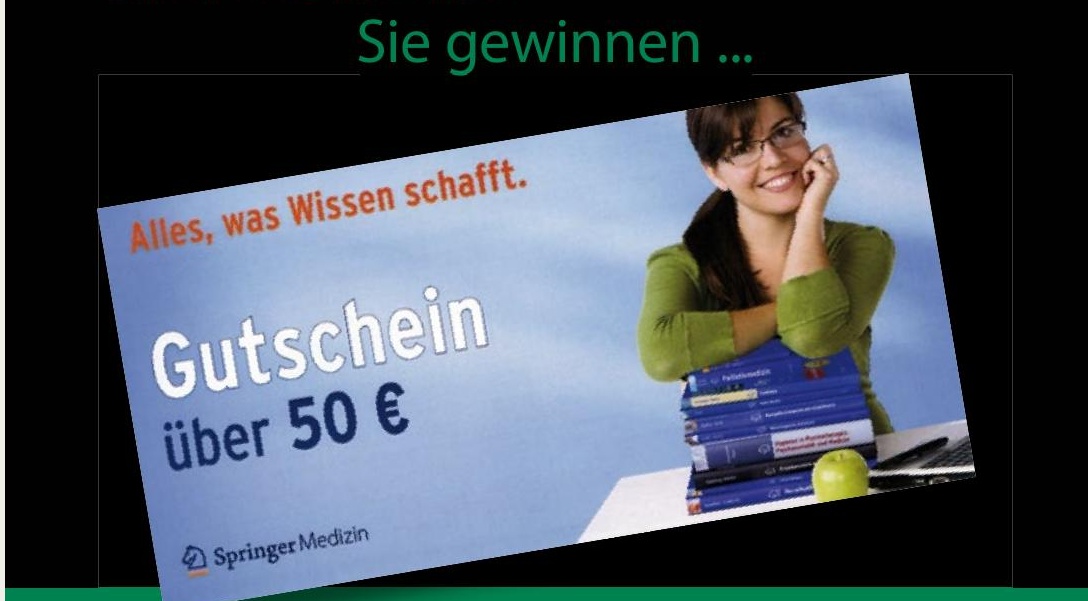

Unter den richtigen

Einsendungen verlosen wir drei Gutscheine über 50 Euro, die Sie für ein beliebiges Springer-Buch einlösen können.

Lösung des Quiz 09/2015 Richtig war: C

Die Gewinne gehen an:

F. Hartmann, 32657 Lemgo

B. Göldner, 01920 Steina

R. Janker, 83646 Bad Tölz

Einsendeschluss ist der

16.12.2015
Herzlichen Glückwunsch! 